\title{
MOLECULAR DETECTION OF RESISTANCE TO BACTERIAL LEAF BLIGHT ON CONDE INDONESIAN RICE VARIETY
}

\author{
Fatimah", Joko Prasetiyono, Aqwin Polosoro, and Mushlihatun Baroya \\ Indonesian Center for Agricultural Biotechnology and Genetic Resources Reserch and Development, \\ Jalan Tentara Pelajar No. 3A, Bogor 16111, Indonesia.
}

\begin{abstract}
Rice bacterial leaf blight (BLB) disease caused by Xanthomonas oryzae pv. oryzae (Xoo) affected grain yield and decreasing rice production in rice growing countries. Conde, Indonesian rice variety, exhibits high resistance to most of the Indonesian races of (BLB) and has been used in Indonesia for cultivated rice. This study was aimed to conduct the molecular detection between proximal markers in chromosome 6 and relative expression of Conde rice variety compare to IRBB7 in $\mathrm{Xa} 7$ region. The population screening, BLB evaluation and molecular detection around the $\mathrm{Xa} 7$ region were conducted. The results showed from the collection of individual recombinants between resistant and susceptible parents narrow the region containing the BTBPOZ domain. The sequence alignment of Xa7LD37 in two resistant and three susceptible cultivars demonstrated a perfect association. The sequence alignment in exon region of Loc_Os06g46240 in Nipponbare, IRBB7, and IR64 identified indel/SNPs in this region leading to nucleotide substitution and frameshift resulting in amino acid change between resistant and susceptible cultivars. It was predicted that Conde revealed the similar gene action with $\mathrm{Xa} 7$ gene for BLB that encodes a BTB POZ domain.
\end{abstract}

Keywords: BTB/POZ domain, dominant gene, Oryza sativa, Xanthomonas oryzae pv. oryzae, Xa7

*Corresponding author: Fatimah

Agricultural campus, Jl. Tentara Pelajar 3A Cimanggu Bogor. West Java. 16111, Indonesia

Tel. +62-21-8754587, Fax. +62-21-87754588

E-mail. fatimahsuw@gmail.com

\section{Introduction}

BLB is extensively damaging disease particularly in tropical irrigated lowland rice environment under suitable condition. Yield losses was estimated at about $15 \%$ and up to $80 \%$ on severely infected field when the disease infected rice at maximum tillering stage (Sudir et al., 2012). At present, most of the existing commercial rice varieties are susceptible to the existing Xoo pathotypes, causing damage to the rice production in the country. Triny (2009) reported that damage due to severe BLB attacks on IR64 and Ciherang varieties. Even though these varieties were released in 1986 and 2000 respectively as a BLB resistance crop however they have been broken down since 2006/2007.

Recently, the availability of molecular markers linked to genes for resistance to this disease has shown tremendous potential and would accelerate breeding programs, especially when other traits are also being evaluated as in pyramiding gene approach. PCR-based markers closely linked to BLB resistance genes would be very useful for efficient marker-assisted breeding selection.

There are over 42 resistance genes to $X$. oryzae pv. oryzae (Busungu et al., 2016). Seven of which have been cloned (Xal, Xa3, $x a 5, X a 10, x a 13, X a 21, X a 26$, and Xa27) (Song et al., 1995; Yoshimura et al., 1998; Iyer and McCouch 2004; Tian et al., 2014; Sun et al., 2004; Gu et al., 2005; Chu et al., 2006; Xiang et al., 2006; Gu et al., 2004). Xal encodes a member of the NBS-LRR class, $x a 5$ encodes the gamma subunit of transcription factor IIA (TFIIA $\gamma$ ). Xa3, Xa21 and Xa26 encode NBS-LRR proteins containing a protein kinase domain. Xal0 encodes ER membrane protein. xal3 confers resistance to the Xoo strains encoding PthXo1 effector (Antony et al., 2010). Xa27 encodes an apoplast protein of 113 amino acids (Wu et al., 2008). 
$\mathrm{Xa} 7$ is a dominant resistance gene and was originally identified in rice cultivar DV85 (Sidhu et al., 1978). The near isogenic line IRBB7 (containing $\mathrm{Xa}$ 7 gene) was developed by crossing DV85 to the susceptible cultivar IR24 (Ogawa et al., 1991). Xa7 is a potential source of durable and broad resistance to BLB (Vera Cruz et al., 2000).

Recently, the $\mathrm{Xa}$ 7 gene has not been isolated, but the avirulence (Avr) gene AvrXa7 corresponding to resistance gene $\mathrm{X} a 7$ has been cloned (Yang et al., 2000). Xa7 was previously located in a region between two markers M1 $(2.2 \mathrm{cM})$ and $\mathrm{M} 3(0.5 \mathrm{cM})$ of chromosome 6 (Porter et al., 2003). Chen et al., (2008) further integrated to the region between two proximal markers GDSSR02 and RM20593, an interval of approximate $118.5 \mathrm{~kb}$. Zhang et al., (2009) had constructed the contig covering the genomic region between two markers RM20576 in contig OSJNBa0032M1 and MY4 in contig B1153E06, an interval of approximately $200 \mathrm{~kb}$.

A previous report on the development of BLB resistance was conducted by Bustamam et al. (2002). They have already developed new lowland rice varieties using markerassisted selection approach and nationally released as Angke variety containing xa5+ $\mathrm{Xa} 4$ gene derived from a cross between IRBB5 and IR64 cultivar and Conde rice variety containing $\mathrm{Xa} 7+\mathrm{Xa} 4$ gene derived from a cross between IRBB7 and IR64 cultivar. They were named after the river's name in West Java and in Yogyakarta, respectively.

The aim of this research was to conduct molecular detection between proximal markers of $\mathrm{Xa} 7$ region in chromosome 6 from the previously reported region and relative expression of Conde rice variety compare to near isogenic line IRBB7.

\section{Materials and Methods}

Population Screening. A screen of approximately $869 \mathrm{BC}_{1: 2} \mathrm{~F} 2$ individuals from a cross between susceptible rice varieties of Ciherang, Inpari 13 and Nipponbare and resistant rice variety Conde. Total genomic DNA was extracted using young leaves collected from seedling stage as described by Dellaporta et al., (1983). All 35 primers were amplified using Biorad Thermal Cycler PCR machine by following PCR conditions: (i) an initial denaturation step of $2 \mathrm{~min}$ at $94{ }^{\circ} \mathrm{C}$, (ii) 30 cycles of 45 second at $94{ }^{\circ} \mathrm{C}, 45$ second at $55{ }^{\circ} \mathrm{C}$ (depend on the primer annealing), $1 \mathrm{~min}$ at $72{ }^{\circ} \mathrm{C}$ and (iii) a final extension step for 5 min at $72^{\circ} \mathrm{C}$ and run on $8 \%$ polyacrylamide electrophoresis gels and silver-stained. Seeds were planted and inoculated with BLB pathogen at 55 to 60 days after planting, and analyzed for phenotyping.

Bacterial growth and inoculation. $X$. oryzae pv. oryzae Race IV was cultured on media containing $20 \mathrm{~g}$ of sucrose, $5 \mathrm{~g}$ of peptone, 0.5 $\mathrm{g} \mathrm{Ca}(\mathrm{NO} 3)_{2}, 0.43 \mathrm{~g} \mathrm{Na}_{2} \mathrm{HPO} 4$, and $0.05 \mathrm{~g}$ $\mathrm{FeSO}_{4}$ per liter and allowed to grow at $28^{\circ} \mathrm{C}$ to $30^{\circ} \mathrm{C}$ for 3 to 4 days. Bacteria was collected into sterile distilled water and adjusted to a concentration of an optical density at $600 \mathrm{~nm}$ $=1$. For phenotyping, the plants were inoculated by the leaf-clipping method (Kauffman et al., 1973) 55 to 65 days after planting and scored 14 days after inoculation. The symptoms were scored as resistant if the average attack intensity is $6 \%$ or less (score 1 $\& 2$ ) and as susceptible if average attack intensity is greater than $6 \%$ (score 3 to 9) (IRRI, 1996).

Molecular Detection. Based on the previous report of $\mathrm{Xa} 7$ gene, Porter et al., (2003) identified three Bacterial Artificial Chromosome (BAC) clone sequences of $O$. sativa cv. Nipponbare, B1472F02, P0778G11 and B1153E06. Chen et al. (2008) employed twelve SSR markers on chromosome 6 that are linked to Xa7. Zhang et al. (2009) narrowed the $X a 7$ gene to an approximately $200-\mathrm{kb}$ segment in the subtelomeric region of chromosome 6 . In addition, in this study, eight anchored primers and 15 primers pair based on DNA sequence around the $X a 7$ region and were developed in the target region through bioinformatics analysis using the reference genome sequences of two subspecies, i.e. japonica (cv. Nipponbare; and indica (cv.9311) (http://www.gramene.org) on chromosome 6 corresponding to the gene annotation released by the TIGR Rice Genome Annotation Version 4 (Figure 1).

RT-PCR and qRT PCR. Leaves tissue was collected from susceptible IR24 and its resistant IRBB7 and Conde variety at 2, 4, 8, 24 , and $48 \mathrm{~h}$ after inoculation in two separate experiments. Uninoculated plants were used as 
controls. Leaves were wounded by tearing a 2to 3-cm piece of leaf tissue. Total RNA was extracted with RNAeasy miniplant RNA extraction kit (Qiagen, Valencia, CA, U.S.A.). Total RNA was amplified into cDNA with RTPCR/qRT-PCR following manufacturer's instructions. As a control, The reaction used for amplification of AK241848 and actin; The cDNA was used for the amplification of AK241848 and CI408865. The amplified PCR products were loaded on $1 \%$ agarose gels and for qRT-PCR using ABI7000. Primers were designed to span introns of $\mathrm{BTB} / \mathrm{POZ}$ domain, hypothetical protein of AK241848 and BTB/POZ domain C1408865 and actin; each reverse primer was anchored in the 3' UTR. BLAST searches were used to ensure that primers were specific to the candidate gene of interest and dimer using PRaTo software.

Sequence analysis of resistant and susceptible accession. Susceptible and resistant accession were chosen from the Indonesian rice germplasms (data not shown). Primers were designed at 0.5 - to $1-\mathrm{kb}$ intervals throughout the $X a 7$ region and used to amplify susceptible and resistant sequences. Amplified products were sequenced at Microgen, South Korea.

Database searches and sequence alignment. Databases at The National Center for Biotechnological Information and The Institute for Genome Research searched using BLAST. Sequences were aligned using the ClustalW program BioEdit. The bioinformatics analysis was conducted in the sequence of Loc_Os06g46240 of IRBB7, Nipponbare and IR64 from oryzaSNP database.

\section{Results}

Population screening. The genotyping identified 4 recombinants within the $150-\mathrm{kb}$ region between SSR markers RM20582 and MY4. Of the individuals, 3 had recombination breakpoints between RM20582 and RM20591, one had breakpoints between RM20582 and RM20589 and between RM20589 and RM20595, one between RM20582 and RM20591. Relevant recombinants occurred within the region containing dominant $\mathrm{Xa} 7$ gene that narrowing the region of $\mathrm{BTB} \mathrm{POZ}$ domain (Figure 1).
BLB Evaluation. The phenotyping revealed the segregation ratios fit well with the expected ratio of dominant gene of $\mathrm{Xa} 7$ as 3R:1S against $X$ oo $\chi 2=1.98$, pval $=0.16$ (Figure 2). The resistant individu was in dominant homozygote condition (RR) while the susceptible individu was in recessive homozygote (rr) and medium resistant was in between (heterozygote condition/Rr) (Figure $1)$.

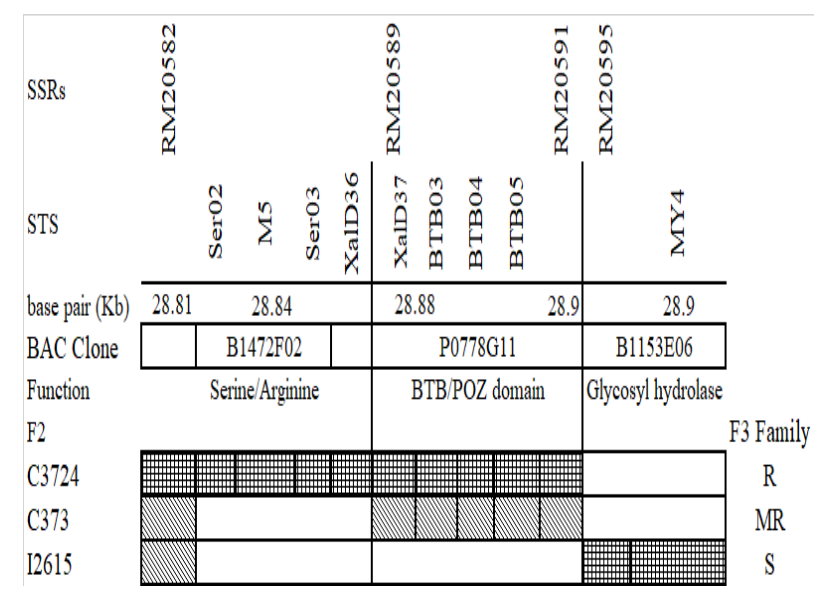

Figure 1. Relevant recombinants within the region containing $\mathrm{Xa}$ 7 gene that allowed narrowing of the region to approximately 10,2 $\mathrm{kb}$ containing BTB POZ domain. SSRs = simple sequence repeats, $\mathrm{STS}=$ Sequence tagged site, $\mathrm{R}=$ resistant (Homozygote/RR), $\mathrm{MR}=$ Medium Resistant (Heterozygote/Rr) and $\mathrm{S}=$ susceptible (Homozygote/rr). Base pairs refer to relative distances along the Nipponbare BAC.

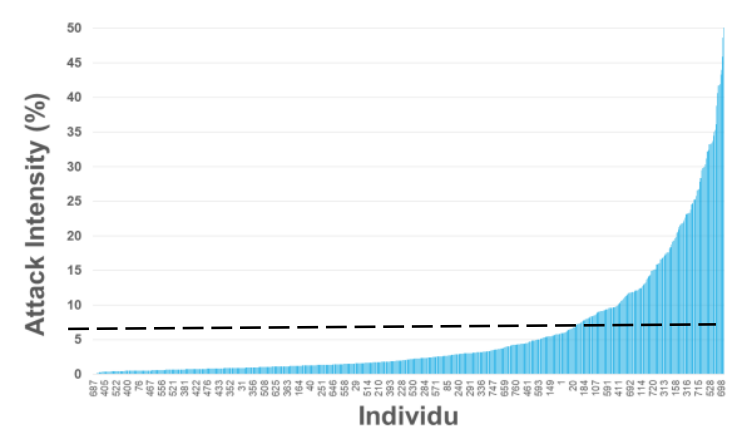

Figure 2. Distribution of BLB intensity (\%) of $869 \mathrm{BC}_{1: 2} \mathrm{~F} 2$ individuals from a cross between susceptible varieties of Ciherang, Inpari 13 and Nipponbare and resistant variety Conde after inoculation with Xoo Race IV at 14 DAI. 
Molecular Detection. The graphical genotype analysis showed the significance of primer Xa7LD37 (2.6; pval $=2.7 \times 10^{-3}, \mathrm{R}^{2}=0.86$ ). It was estimated the region located on BAC clone P0778G11 on Loc_Os06g46240 in region $28007285-28017490 \mathrm{bp}(10.2 \mathrm{~kb})$ on rice genome (Figure 3). It was known as BTB/POZ domain-containing protein, putative, expressed. The gene structure of Loc_Os06g46240 contained 14 exons, transcript length 3345 bps and translation length 1114 bp (MSU Rice Genome Annotation project).

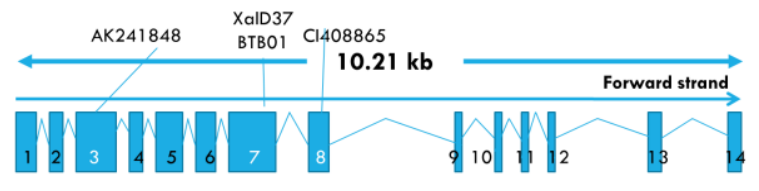

Figure 3. The gene structure of Loc_Os06g46240 (MSU Rice Genome Annotation project).

To further explore the association between this sequence polymorphism (genotype) and the BLB evaluation (phenotype) in local varieties, the sequenced varieties are listed in Table 1. The sequence of Xa7LD37 primer in the region of $\mathrm{BTB} / \mathrm{POZ}$ domain revealed nucleotide substitutions in two resistants (Rasi and Relly) and 3 susceptible accessions (Ase Pulu Bolong, Keran Dukuh, and Ketan Papah Aren). The result showed two resistant haplotype conserved across all 2 resistant lines and three haplotypes among the 3 susceptible accessions. The Nipponbare and Ase Pulu Bolong contained the same susceptible haplotype as IR64 and other haplotype was Keran Dukuh and Ketan Papah Aren while Rasi the same resistant haplotype as IRBB7 and other haplotype was Relly (Figure 4).

Table 1. List of Indonesian local rice germplasm used in research.

\begin{tabular}{|c|c|c|c|c|c|}
\hline No. & $\begin{array}{l}\text { Accs. } \\
\text { No. }\end{array}$ & $\begin{array}{l}\text { Accs } \\
\text { Name }\end{array}$ & Origin & $\begin{array}{l}\text { Xoo } \\
\text { (Race } \\
\text { IV) } \\
\end{array}$ & $\begin{array}{l}\text { Hapl } \\
\text { otype }\end{array}$ \\
\hline 1 & 10221 & $\begin{array}{l}\text { Ase } \\
\text { Pulu } \\
\text { Bolong }\end{array}$ & $\begin{array}{l}\text { South } \\
\text { Sulawesi }\end{array}$ & $\mathrm{S}$ & S1 \\
\hline 2 & 20514 & $\begin{array}{l}\text { Karang } \\
\text { Dukuh }\end{array}$ & $\begin{array}{l}\text { Central } \\
\text { Kalimantan }\end{array}$ & $\mathrm{S}$ & S2 \\
\hline 3 & 5205 & $\begin{array}{l}\text { Ketan } \\
\text { Papah } \\
\text { Aren }\end{array}$ & $\begin{array}{l}\text { Gunungkidu } \\
\text { 1, DIY }\end{array}$ & $\mathrm{S}$ & S3 \\
\hline 4 & 4176 & Rasi & Aceh & $\mathrm{R}$ & R1 \\
\hline 5 & 3983 & Relly & $\begin{array}{l}\text { West } \\
\text { Kalimantan }\end{array}$ & $\mathrm{R}$ & R2 \\
\hline
\end{tabular}

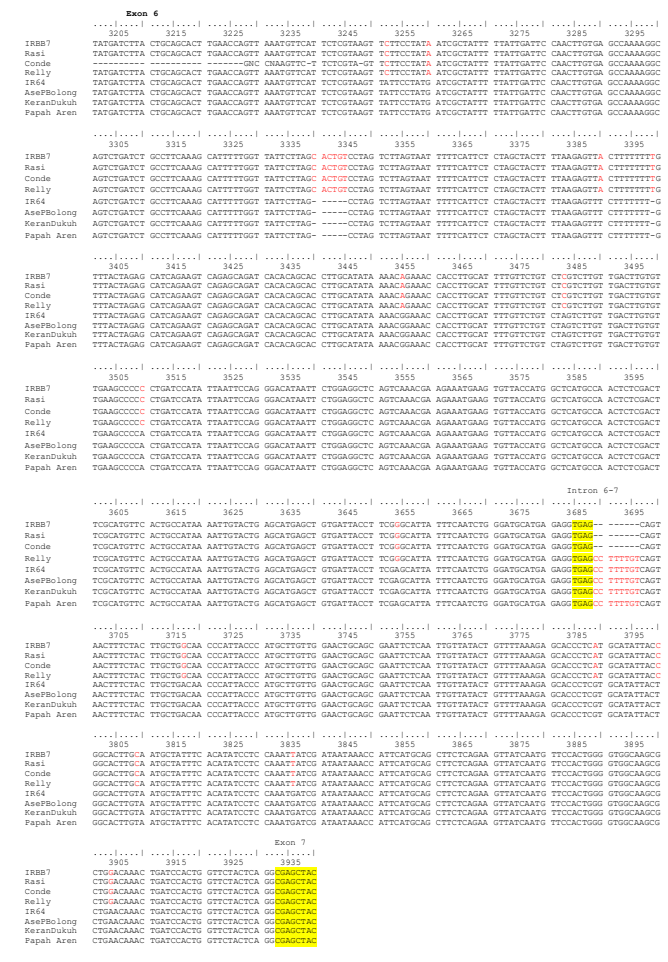

Figure 4. Sequence alignment of IRBB7, Conde, and two Indonesian rice germplasm (Rasi and Relly) as resistant accession and IR64 and three Indonesian rice germplasm Ase Pulu Bolong, Keran Dukuh, Papah Aren as susceptible accession using primer Xa7LD37 identified the SNPs difference between the resistant and susceptible cultivars. Xa7LD37 lied in region of Exon 6 and Intron 6-7 of Loc_Os06g46240.

To investigate the possible function of the polymorphisms in the Loc_Os06g46240. Two possible exons were chosen. The first exon of AK241848 was in exon 3 while the second exon was CI40886 in exon 8. The first and second exon were analyzed by RT-PCR and qRT-PCR.

Relative expression analysis. The expression patterns of AK241848 and CI40886 were compared to susceptible and resistant plants, with and without inoculation with race IV of Xoo. RT-PCR analysis showed that transcripts from AK241848 and CI40886 were detectable in resistant and susceptible cultivars at all time points (Figure 5 and 6). The resistant line IRBB7 and Conde, CI40886 showed high intensity in IRBB7 rather than in Conde at all time points while in IR24 the expression was higher in $2 \mathrm{~h}$ and $4 \mathrm{~h}$ PI rather than $8 \mathrm{~h}, 24 \mathrm{~h}$, and 48h PI. In AK241848 the expression in IRBB7 
and Conde was higher in $4 \mathrm{~h}, 8 \mathrm{~h}, 24 \mathrm{~h}$ and decrease in $48 \mathrm{~h}$ while in susceptible line IR24 the expression was high in all time points. Then, the analysis of $A K 241848$ was pursued for relative expression analysis using qRTPCR (Figure 7).

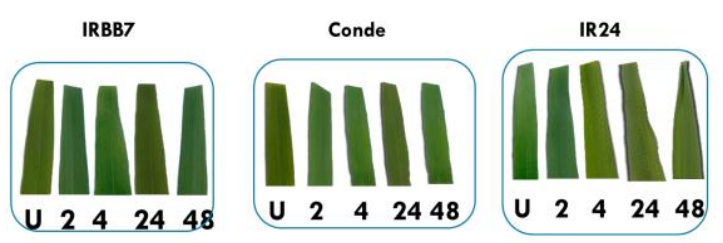

Figure 5. Leaf phenotype of IRBB7, Conde and IR24 as an example showing reaction to Xoo Race IV. Leaf 1, uninoculated plants; leaf 2, 2 h postinoculation (PI) with Xoo race IV; leaf 3, 4 h PI; leaf 4, 8 h PI; leaf 5, 24 h PI; and lraf 6, 48 h PI. Leaves were photographed hours after inoculation.

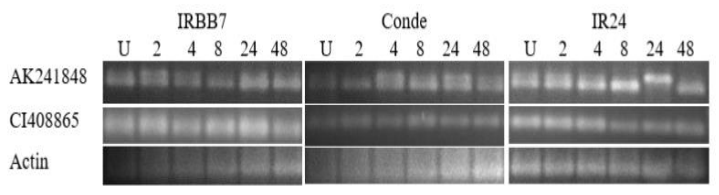

Figure. 6. Reverse transcription-polymerase chain reaction (RT-PCR) analysis of AK241848 and CI40886. The experiment was repeated two times, and typical results are shown. Lane 1, uninoculated plants; lane 2, $2 \mathrm{~h}$ postinoculation (PI) with Xoo race IV; lane 3, $4 \mathrm{~h} \mathrm{PI}$; lane 4, 8 h PI; lane 5, $24 \mathrm{~h} \mathrm{PI}$; and lane 6, 48 h PI.

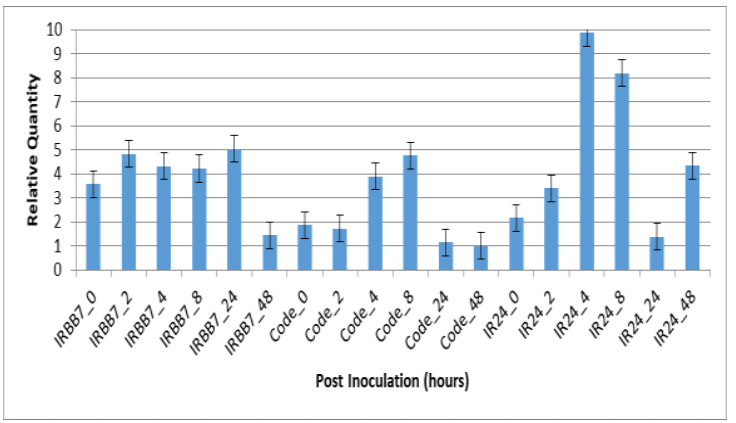

Figure 7. The histogram of qRT-PCR analysis of AK241848. The experiment was repeated three times, 0 : uninoculated plants; $2: 2 \mathrm{~h}$ postinoculation (PI) with Xoo race IV, $4: 4 \mathrm{~h}$ PI; 8: 8 h PI; 24: 24 h PI; and 48: 48 h PI.

In the resistant line of IRBB7, similar expression of 2,4,8, and 24h PI and decreased in $48 \mathrm{~h}$ PI while in variety of Conde the relative expression increased in $4 \mathrm{~h}$ and $8 \mathrm{~h}$ PI and decreased in $24 \mathrm{~h}$ and $48 \mathrm{~h}$ PI. In the susceptible line of IR24, the relative expression increased in $4 \mathrm{~h}$ and $8 \mathrm{~h}$ PI, however, it decreased in $24 \mathrm{~h}$ PI and continued increasing in $48 \mathrm{~h}$ PI. The expression of IRBB7 was stable rather than that of Conde. Although Conde giving similar pattern (increasing in $4 \mathrm{~h}$ and $8 \mathrm{~h}$ PI) with IR24, however, the relative expression was lower in Code (2 times) rather than IR24 (5 times) (Figure 7).

Sequence alignment of Loc_Os06g46240. The start codon, splice junctions, and 3' UTR of the Loc_Os06g46240 of Nipponbare to IR64 (susceptible) BAC and aligned to IRBB7 (resistant). This identified $\sim 78$ nucleotide substitutions resulting in an amino acid substitution, in AK241848 from Arginine to glutamic acid to glutamine in the resistant cultivar while in CI40886 from valine to glycine and glycine to serin, a significant change from a hydrophobic to semihydrophilic amino acid. The deletion of $\mathrm{A}$ in resistant cultivar leading to frameshift at the end of exon 11, the whole part of exon 12 and at the beginning exon 13, from 971 to 1011 amino acid. There is 104 bp deletion in resistant cultivar in exon 1 , however, the deletion was identical in Nipponbare (susceptible) and IRBB7 (resistant), indicating that they do not play a role in $X a 7$ resistance (Figure 8).

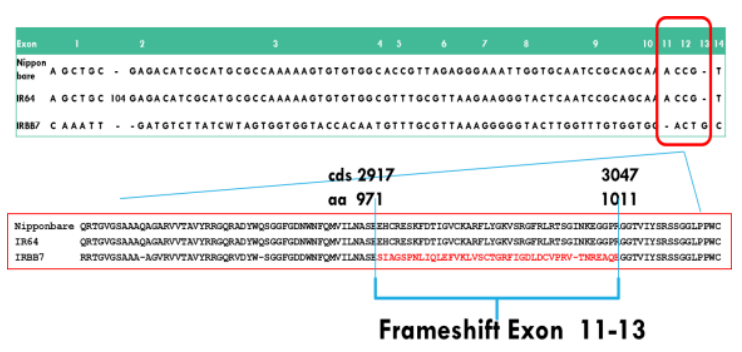

Figure 8. Sequence alignment of indel/SNPs in exon region of Loc_Os06g46240 in Nipponbare, IRBB7, and IR64 leading to amino acid substitution and frameshift.

\section{Discussion}

The resistance gene that identified in Conde variety was located on the long arm of chromosome 6. In this region, two dominant genes (Xa7 and Xa27) (Sidhu et al., 1978; Gu et al., 2004) and recessive gene $x a 33(\mathrm{t})$ (Korinsak et al., 2009) have been reported. 
Even though $X a 7$ and $x a 33(\mathrm{t})$ shared commonly linked markers, however, $\mathrm{Xa} 7$ and $x a 33(t)$ had shown different gene actions and specificity in responding to BLB isolates. $\mathrm{Xa27}$ was reportedly located between RFLP markers RG424-RG162 (70.4-104.6 cM, Cornell map) on the long arm of chromosome 6, which was about $22.1 \mathrm{cM}$ away from xa33(t) and Xa7. In the $x a 33(\mathrm{t})$, the segregation ration was $1 \mathrm{R}: 3 \mathrm{~S}$ in which gene governing the resistance acted as recessive.

Bric-a-brac, Tramtrack and Broad Complex/Pox virus and Zinc finger (BTB/POZ) domain that is known to mediate both homo- and heterodimerization (Bardwell et al., 1994; Zollman et al., 1994). The Arabidopsis genome encodes at least seventysix BTB domain proteins that can be classified into eleven major families according to their domain architecture (Dieterie et al., 2004). BTB proteins seem to be involved in a broad range of processes, such as systemic acquired resistance (Cao et al., 1997) and targeted proteolysis (Pintard et al., 2003; Figueroa et al., 2005). Jiang et al. (2006) reported the molecular characterization and functional investigation on OsBTB gene induced by Magnaporthe grisea in Rice blast disease.

Based on some experimental observations, in this report, it was predicted that Conde rice variety revealed the similar gene action with $X a 7$ gene for BLB that encodes a $B T B P O Z$ domain. First, a collection of individual recombinants between resistant (Conde) and susceptible parents (Ciherang, Inpari 13 and Nipponbare) allowed to narrow the $X a 7$ region in resistant rice variety (IRBB7 and Conde) to an approximately $10.2-\mathrm{kb}$ interval containing the BTBPOZ domain. Second, sequencing alignment of $\mathrm{Xa}$ gene using Xa7LD37 primer in two resistant (Rasi and Relly) and three susceptible accessions (Ase Pulu Bolong, Keran Dukuh, and Ketan Papah Aren). demonstrated a perfect association between the haplotype and resistance to race IV of Xoo. Third, sequence alignment in exon region of Loc_Os06g46240 in Nipponbare, IRBB7, and IR64 cultivars identified indel/SNPs in this region leading to nucleotide substitution and frameshift that resulting in amino acid change between resistant and susceptible cultivars.

\section{Acknowledgements}

The author would like to gratefully acknowledge Mahrup for technical assistance and greenhouse maintenance. This work was financially supported by ITSF year 2014 .

\section{References}

Antony, G., Zhou, J., Huang, S., Li, T., Liu, B., White, F., \& Yang, B. (2010). Rice xal3 Recessive Resistance to Bacterial Blight is Defeated by Induction of the Disease Susceptibility Gene Os-11N3. Plant Cell, 22(11),3864-3876.doi:10.1105/tpc.110.078964

Bardwell, V. J., \& Treisman, R. (1994). The POZ domain: a conserved protein-protein interaction motif. Genes Dev, 8,1664-1677.

Bustamam, M., Tabien, R. E., Suwarno, A., Abalos, M. C., Kadir, T. S., Ona, I., Bernardo, M., Veracruz, C. M. \& Leung, H. (2002). Asian Rice Biotechnology Network: Improving Popular Cultivars through Marker-Assisted Backcrossing By The Nares. - Poster at the International Rice Congress, Beijing, China.

Busungu, C., Taura, S., Sakagami J.I., \& Katsuyuki I. (2016). Identification and linkage analysis of a new rice bacterial blight resistance gene from XM14, a mutant line from IR24. Breeding Science, 66, 636-645 doi:10.1270/jsbbs.16062.

Cao, H., Glazebrook, J., Clarke, J.D., Volko, S., \& Dong, X. (1997). The Arabidopsis NPR1 Gene That Controls Systemic Acquired Resistance Encodes a Novel Protein Containing Ankyrin Repeats. Cell, 88, 57-63.

Chen, S., Huang, Z., Zeng, Li., Yang, J., Liu, Q., \& Zhu, X. (2008). High-resolution mapping and gene prediction of Xanthomonas oryzae pv. oryzae resistance gene Xa7. Mol Breeding, 22,433-441.

Chu, Z., Yuan, M., Yao, J., Ge, X., Yuan, B., Xu, C., Li, X., Fu, B., Li, Z., Bennetzen, J.L., Zhang, Q., \& Wang, S. (2006). Promoter mutations of an essential gene for pollen development result in disease resistance in rice. Gene Dev, 20,1250-1255.

Dellaporta, S.L., Wood, J., \& Hicks, J.B. (1983). A plant DNA minipreparation: version II. Plant Mol Biol Rep, 1,19-21.

Dieterie, M., Thomann, A., Renou, J.P., Parmentier, Y., Cognat, V., Lemonnier, G., Muller, R., Shen, W.H., Kretsch, T., \& Genschik, P. (2005). Molecular and functional characterization of Arabidopsis Cullin 3A. Plant J, 41,386-399.

Figueroa, P., Gusmaroli, G., Serino, G., Habashi, J., Ma, L.G., Shen,Y.P., Feng, S.H., Bostick, M., Callis, J., Hellmann, H., \& Deng, X.W. (2005). Arabidopsis has two redundant Cullin3 proteins 
that are essential for embryo development and that interact with $\mathrm{RBX} 1$ and $\mathrm{BTB}$ proteins to form multisubunit E3 ubiquitin ligase complexes in vivo. Plant Cell, 17,1180-1195.

Gu, K., Tian D., Yang, F., Wu, L., Sreekala C., Wang, D., Wang, G.L., \& Yin, Z. (2004). Highresolution genetic mapping of $X a 27(\mathrm{t})$, a new bacterial blight resistance gene in rice, Orysa sativa L. Theor Appl Genet, 108, 800-807.

Gu, K.Y., Yang, B., Tian, D.S., Wu, L.F., Wang, D.J., Sreekala, C., Yang, F., Chu, Z.Q., Wang, G.L., White, F.F., \& Yin, Z.C. (2005). R gene expression induced by a type-III effector triggers disease resistance in rice. Nature, 435 , $1122-1125$.

IRRI (1996) Standard evaluation system for rice. $4^{\text {th }}$ Edition, IRRI, Philippines.

Iyer, A.S., \& McCouch, S.R. (2004). The rice bacterial blight resistance gene $x a 5$ encodes a novel form of disease resistance. Mol PlantMicrobe Interact, 17,1348-1354.

Jiang, Y.X., Dong, H.T., Zhuang, J.Y., Zheng, K.L., \& Li, D.B. (2006). A preliminary molecular characterization and functional investigation on OsBTB gene induced by Magnaporthe grisea in Rice. Chinese J Rice Sci,20,577-582.

Kauffman, H.E., Reddy, A.P.K., Hsieh, S.P.Y., \& Merca, S.D. (1973). An improved technique for evaluating resistance of rice varieties to Xanthomonas oryzae pv. oryzae. Plant Diseases Rep, 57,537-541.

Korinsak, S., Sriprakhon, S., Sirithanya, P., Jairin, J., Korinsak, S., Vanavichit, A., \& Toojinda, T. (2009). Identification of microsatellite markers (SSR) linked to a new bacterial blight resistance gene $x a 33(\mathrm{t})$ in rice cultivar 'Ba7'. Maejo Int $J$ Sci Technol, 3,235-247.

Ogawa, T., Yamamoto, T., Khush, G.S., \& Mew, T.W. (1991). Breeding of near isogenic lines of rice with single genes for resistance to bacterial blight pathogen (Xanthomonas campestris pv oryzae). Japan J Breed, 41,523-529.

Pintard, L., Willis, J.H., Willems, A., Johnson, J.L.F., Srayko, M., Kurz, T., Glaser, S., Mains, P.E., Tyers, M., Bowerman, B., et al. 2003. The BTB protein MEL-26 is a substrate-specific adaptor of the CUL-3 ubiquitin-ligase. Nature, 425,311-316.

Porter, B.W., Chittoor, J. M., Yano, M., Sasaki, T., \& White, F.F. (2003). Development and mapping of markers linked to the rice bacterial blight resistance gene Xa7. Crop Sci, 43:14841492.

Sidhu, G.S., Khush, G.S., \& Mew. T.W. (1978). Genetic analysis of bacterial blight resistance in seventy-four cultivars of rice, Oryza sativa L. Theor Appl Genet, 53,105-111.

Song, W.Y., Wang. G.L., Chen, L.L., Kim, H.S., Pi, L.Y., Holston, L.Y., Gardner, T., Wang, B.,
Zhai, W.X., Zhu, L.H., Fauguet, C., \& Ronald, P. (1995). A receptor kinase-like protein encoded by the rice disease resistance gene Xa21. Science, 270,1772-1804.

Sudir, Nuryanto, B., \& Kadir, T.S. (2012). Epidemiologi, Patotipe, dan Strategi Pengendalian Penyakit Hawar Daun Bakteri pada Tanaman Padi. IPTEK Tanaman Pangan, 7 (2), 79-87.

Sun, X., Cao, Y., Yang, Z., Xu, C., Li, X., Wang, S., \& Zhang, Q. (2004). Xa26, a gene conferring resistance to Xanthomonas oryzae pv. oryzae in rice, encodes an LRR receptor kinase-like protein. Plant J, 37, 517-527.

Tian, D., Wang, J., Zeng, X., Gu, K., Qiu, C., Yang, X., Zhou, Z., Goh, M., Luo, Y., MurataHori, M., White, F. F., \& Yin, Z. (2014). The Rice TAL Effector-dependent Resistance Protein Xa10 Triggers Cell Death and Calcium Depletion in the Endoplasmic Reticulum. Plant Cell 26, 497-515.

Triny, S.K., Suryadi, Y. Sudir, \& Machmud, M. (2009). Penyakit bakteri padi dan cara pengendaliannya. IAARD, p 499-530.

Vera cruz, C.M. Bai, J., Ona, I., Leung, H., Nelson, R.J., Mew, T.W. \& Leach, J.E. (2000). Predicting durability of a disease resistance gene based on an assessment of the fitness loss and epidemiological consequences of avirulence gene mutation. Proc Natl Acad Sci, 97,1350013505.

Wu, L., Goh, M. L., Sreekala, C., \& Yin, Z. (2008). Xa27 Depends on an Amino-terminal Signalanchor-like Sequence to Localize to the Apoplast for Resistance to Xanthomonas oryzae pv. oryzae. Plant Physiol, 148, 1497-1509.

Xiang, Y., Cao, Y.L., Xu, C.Q., Li, X.H., \& Wang, S.P. (2006). Xa3, conferring resistance for rice bacterial blight and encoding a receptor kinaselike protein, is the same as Xa26. Theor Appl Genet, 113,1347-1355.

Yang, B., Zhu, W., Johnson, L.B., \& White, F.F. (2000). The virulence factor AvrXa7 of Xanthomonas oryzae pv. oryzae is a type III secretion pathway dependent nuclear-localized double-stranded DNA-binding protein. Proc Natl Acad Sci, 97,9807-9812.

Yoshimura, S., Yamanouchi, U., Katayose, Y., Toki, S., Wang, Z.X., Kono, I., Kuruta, N., Yano, M., Iwata, N., \& Sasaki, T. (1998). Expression of $\mathrm{Xal}$, a bacterial blight resistance gene in rice, is induced by bacterial inoculation. Proc Natl Acad Sci,95,1663-1668.

Zhang, Y., Wang, J., Pan, J., Gu, Z., Chen, Z., Jin, Y., Liu, F., Zhang, H., \& Ma, B. (2009). Identification and molecular mapping of the rice bacterial blight resistance gene allelic to $\mathrm{Xa} 7$ from an elite restorer line Zhenhui 084. Eur J Plant Pathol, 125, 235-244. 
Zollman, S., Godt, D., Prive, G. G., Couderc, J. L. \& Laski, F. A. (1994). The BTB domain, found primarily in zinc finger proteins defines an evolutionarily conserved family that includes several developmentally regulated genes in Drosopilla. Proc. Natl Acad Sci, 91,1071710721. 